\title{
Morphological and Quantitative Analyses of the NADH-d Myenteric Neurons of the Jejunum of Rats Submitted to Experimental Chronic Alcoholism
}

\author{
Análisis Morfológico y Cuantitativo de de Neuronas Mientéricas NADH-d del Yeyuno de Ratas \\ Sometidas a Alcoholismo Crónico Experimental \\ "Marli Aparecida dos Santos Pereira; *"Márcia Alessandra Arantes; "Sonia Lucy Molinari; \\ "Jacqueline Nelisis Zanoni \& "Marcílio Hubner de Miranda-Neto
}

PEREIRA, S. M. A.; ARANTES, M. A.; MOlinARI, S. L.; ZANONI, J. N. \& MIRANDA-NETO, M. H. Morphological and quantitative analyses of the NADH-d myenteric neurons of the jejunum of rats submitted to experimental chronic alcoholism. Int. $\boldsymbol{J}$. Morphol., 24(3):391-398, 2006.

SUMMARY: The objective of our work was to verify, during an experimental period of 210 days, the possible effects of the ethanol on the morphology and density of the NADH-diaforase myenteric neurons in the jejunum of alcoholic rats. We used 10 animals (Rattus norvegicus) separated in 2 groups: the controls $(n=5)$, that received a normal proteic diet $(22 \%)$ and water ad libitum; the alcoholic, that received NUVILAB normal proteic chow (22\%) and sugar cane brandy diluted at 30 Gay Lussac ( $\left.30^{\circ} \mathrm{v} / \mathrm{v}\right)$. The jejunum segment was collected and submitted to the histochemical technique to stain the nervous cells and, then, to the elaboration of membrane whole mounts. The observation through light microscopy showed that there are no expressive morphologic differences between the ganglia of neurons of the control and alcoholic rats. The counting of neurons, carried out in 40 microscopic fields $\left(8.96 \mu \mathrm{m}^{2}\right)$ in the control group, at the mesenteric and antimesenteric regions, found 1,131 and 693 neurons respectively, while, the alcoholic group found 1,229 and 860 neurons. The significant increase in the number of neurons in the mesenteric region, in the alcoholic rats, is due to the smaller physical growth of those animals when compared to the controls. The ethanol caused malnutrition and consequently the alcoholic rats showed a larger neuronal density due to its smaller dispersion.

KEYWORDS: Jejunum; Myenteric neurons; Rats; Alcoholism.

\section{INTRODUCTION}

The more frequent neurological lesions in alcoholism are those in the peripheral nervous system. The alcoholic neuropathy is basically an affection due to the nutritious deficit caused by the lack of thiamin, vitamin B-12 and to B-complex (Hoyumpa et al., 1977; Marcus \& Coulston, 1985). Alcohol blocks the conduction in the peripheral nerves, decreasing the maximum values of the sodium and potassium conductance (Ritchie, 1985). The alcoholism peripheral neuropathies, caused either by the toxic effect or the vitamin deficit, are axoniopathies. This means that they are initially caused by changes in the axon, which may be followed by the destruction of the myelin sheat and even by the neuron cellular body (Levy, 1991)

It is known that in order to the small intestine carry out its digestion and absorption functions, there must be a compatibilization of the bolus traffic speed with the accomplishment of both functions. The control of the intestinal motility is performed by the intrinsic innervation, represented by the neurons of the myenteric plexus. They do not depend on the CNS operation (Furness \& Costa, 1980; Sternini, 1988) although the sympathetic and parasympathetic fibers may activate or inhibit this function (Snell, 1985; Gershon, 1981).

About one-third to half of alcohol abusers frequently suffer from diarrhea (Preedy et al., 1993). It is well documented in the literature that the gastric and intestinal mobility is modified by the chronic consumption of alcohol, (Robles et al., 1974; Krishnamra \& Limlomwongse, 1987; Bode \& Bode, 2003). On the other hand, the effects of the chronic ingestion of ethanol on the neurons of the myenteric

\footnotetext{
* Departament of Morphophysiological, State University of Maringá, Paraná, Brazil.

** Acadêmica do Curso de Medicina, State University of Maringá, Paraná, Brazil.
} 
plexus have been relatively unknown, although the intestinal motility is controlled mainly by the nervous cells of that plexus. In order to correlate anatomical changes of the myenteric nervous system with the intestinal dysfunctions observed in the chronic alcohol dependents, we decided to verify the possible hazardous effects of the ethanol on the morphology and density of the NADH-diaforase myenteric neurons in the jejunum of rats, 210 days after our experimental treatment.

\section{MATERIAL AND METHOD}

Ten male Wistar rats (Rattus norvegicus), 60 days of age, were used. The animals were from the Central Biotery of the State University of Maringá. They were kept in individual cages, for 210 days, with controlled temperature and photo-period (12 hours). The animals were divided in 2 groups. The controls $(\mathrm{C}), \mathrm{n}=5$ received NUVILAB chow (recommended by the National Research Council \& National Institute of Health - USA) with normal protein content (22\%) and water ad libitum; the alcoholic group (A) $n=5$ received NUVILAB chow with normal protein content (22\%) and sugar cane brandy ("51"trademark, 39 GL., Indústrias Muller, Pirassununga, SP. Brasil), diluted to 30 Gay Lussac (30 v/v) (Cagnon et al., 1996; Pereira et al., 2003a.; Pereira et al., 2003b; Molinari et al., 2004) ad libitum. We used the semi-voluntary model of alcoholism, in which the only source of available liquid for the animal was the alcoholic one.

After the 210-day period the animals were killed through inhalation of ethylic ether. After a laparotomy, segments of the jejunum were collected, washed and submitted to the histochemical technique to stain the nerve cells through the activity of the NADH-diaphorase (NADHd) enzyme (Gabella 1969). To do so, the jejunum were washed and filled with Krebs solution, without stretching the organ. They were immersed for five minutes in a Triton X-100 $0.3 \%$ solution (Sigma, St. Louis, MO, USA) and then they were washed again in Krebs. The segments were immerged in a medium containing b-NADH (Sigma, St. Louis, MO, USA) and Nitro Blue Tetrazolium (Sigma, St. Louis, MO, USA), for 45 minutes (Gabella, 1969). The reaction was interrupted with buffered formol. The NADH diaforase product reaction appears as a blue/purple coloration of different shades.

The jejunum segments, opened at the mesenteric region, were submitted the accomplishment of the membrane whole-mount. That consisted on the microdissection under stereomicroscope to remove the mucosa and the submucosa; dehydration; clearing and mounting between lamina and cover glass with synthetic resin Permount.

The membrane whole mount was divided in regions according to the outline (Figs.1A and 1B). The NADH-d positive neurons were quantified in the mesenteric and antimesenteric regions. Counting was accomplished by sampling. The neurons of 40 microscopic fields $\left(8.96 \mathrm{~mm}^{2}\right)$ of each region were counted, for both experimental groups. The statistical analyses were carried out with the aid of software from the Department of Statistics of the State University of Maringá, Brazil. The variables that dealt with means were analyzed by the test "t" of Student. The significance level we choose was 5\%. All results were expressed as mean (M) \pm mean \pm standard deviation (SD).

Fig. 1 ( A and B). The whole-mount scheme. Mesenteric, antimesenteric and intermediate regions.

A)

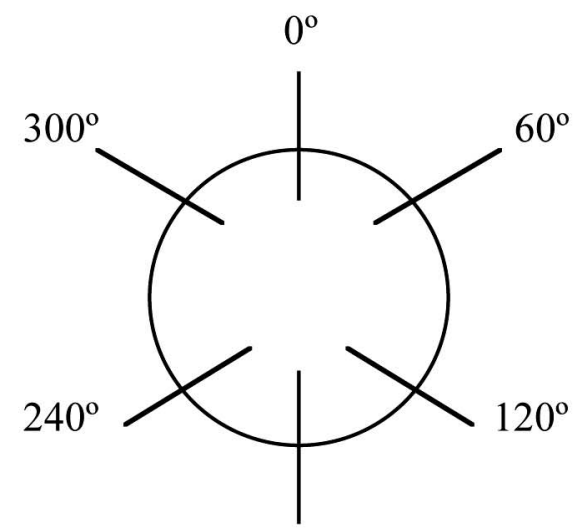

$180^{\circ}$
B)

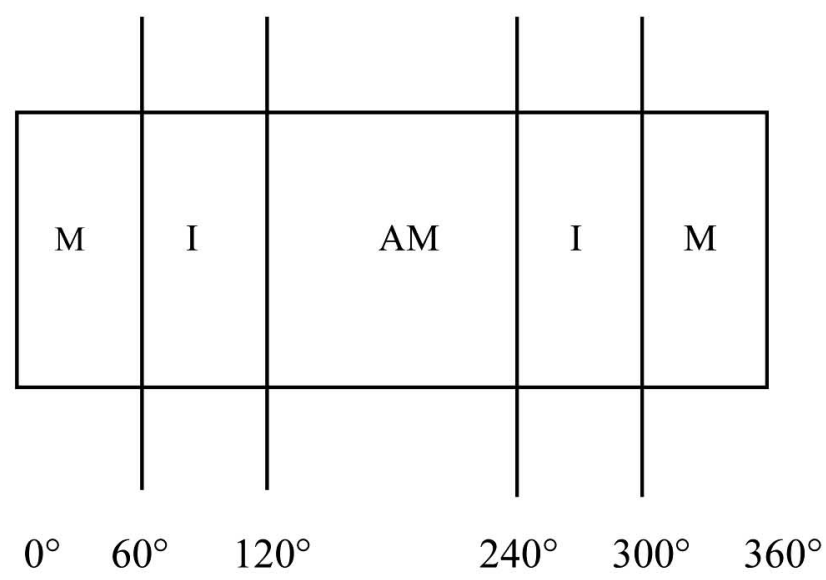




\section{RESULTS}

Table I shows the rats' initial and final body weight as well as their consumption of liquid and solid diets.

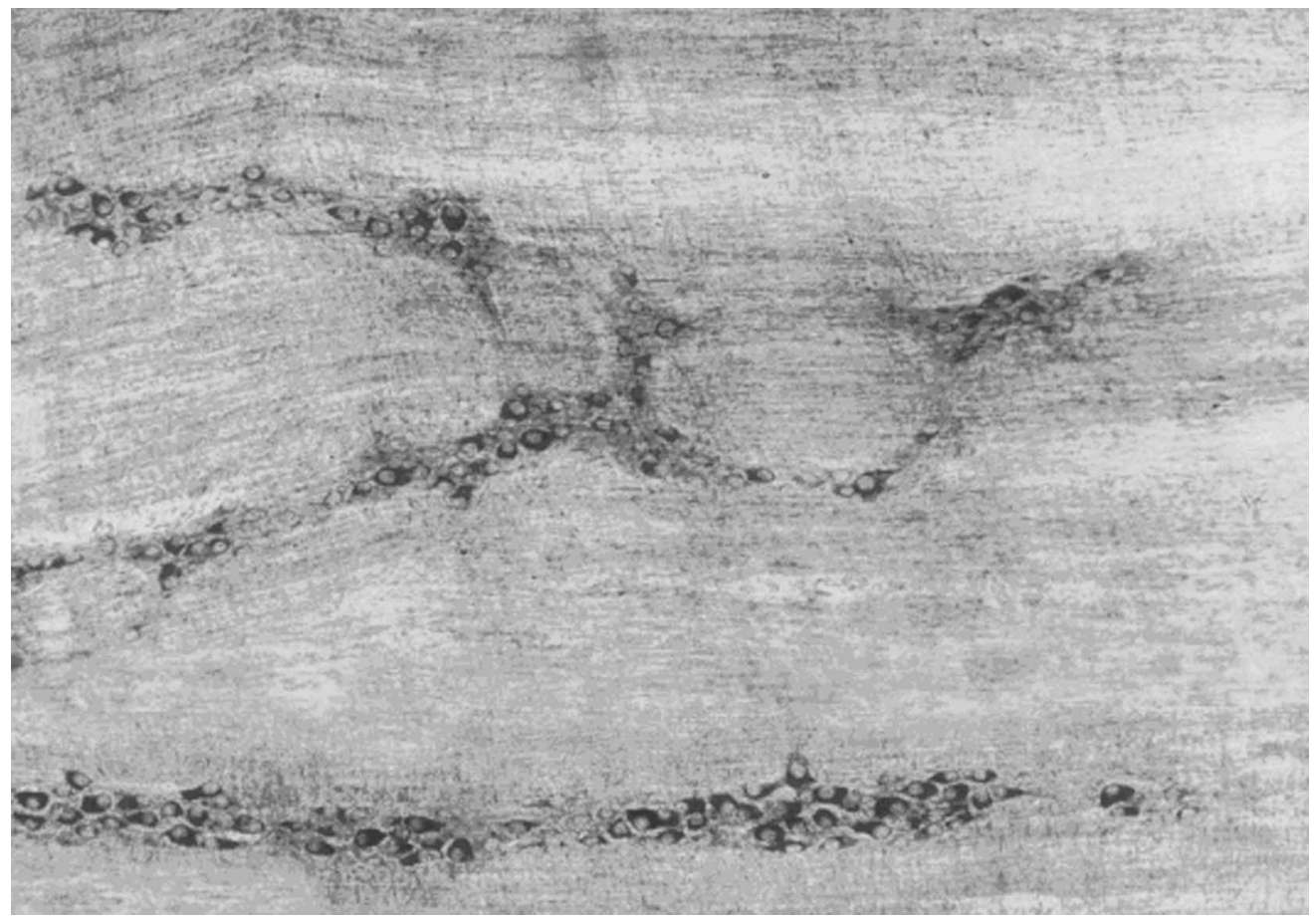

Fig. 2. Whole-amount of the jejunum. Mesenteric region, control rats. Myenteric neurons NADH- d positive gather in ganglia predominantly elongated. 151X.

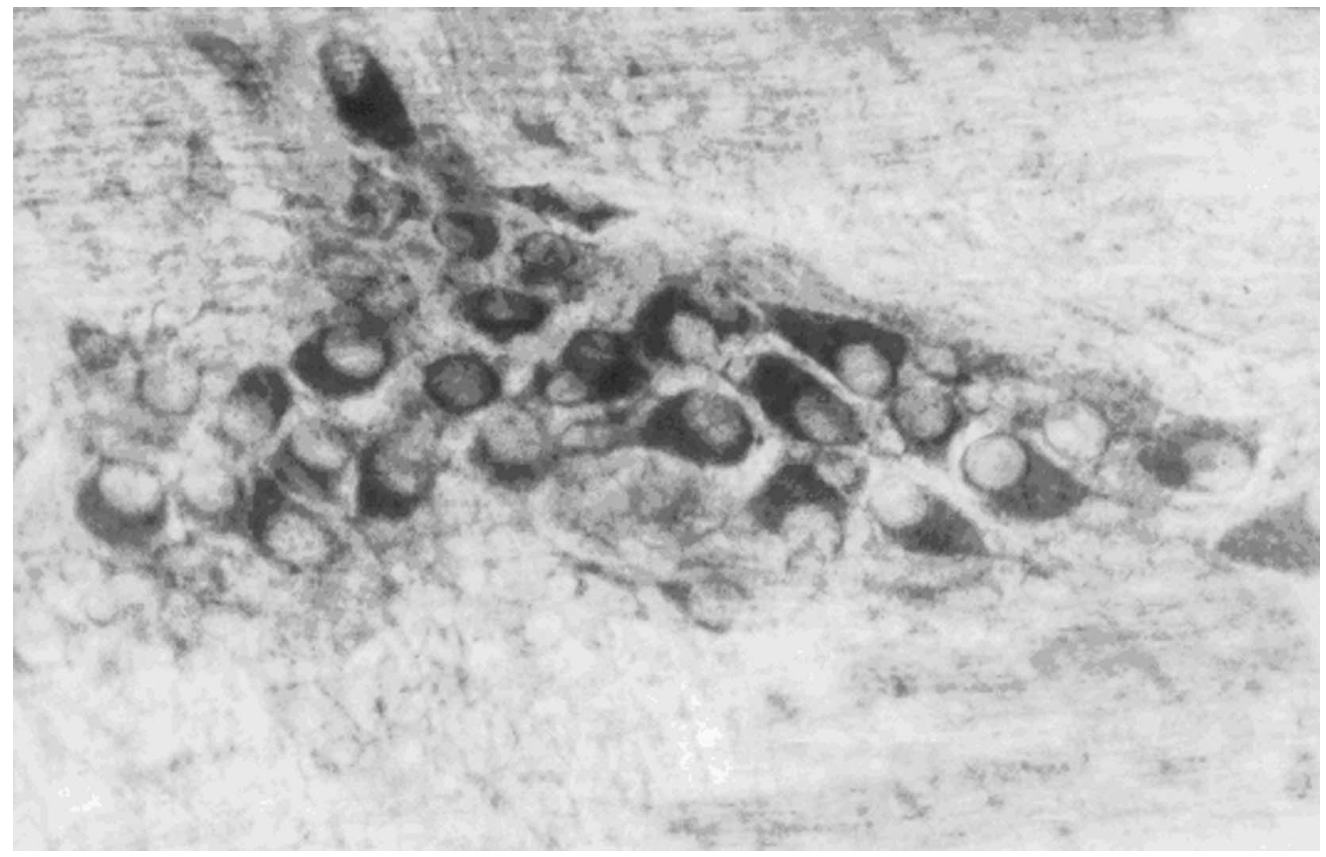

Fig.3. Whole-amount of the jejunum. Mesenteric region, alcoholic rats. NADH-d positive myenteric neurons. The ganglia is formed by bodies of neurons of different sizes and eccentric nuclei.306X. activity, the neurons usually gather and form ganglions. The ganglions are rounded, rectangular and predominantly elongated, disposed obliquely around the intestinal wall and parallel amongst themselves (Fig. 2). The ganglions morphology is similar in the studied region, i.e., in the mesenteric and antimesenteric.

The ganglions are formed by bodies of neurons of different sizes, with different levels of enzymatic activity and eccentric nuclei. Most of them do not have evident nucleoli (Fig. 3). We did not observe significant morphologic differences in the neurons and ganglions for both groups, when we used the light microscopy, after 210 days of treatment.

The statistical analysis for the neuronal density neuronal between the mesenteric and antimesenteric regions, for both groups, is shown in Table II. Table III shows the differences between both groups in the same regions. 
PEREIRA, S. M. A.; ARANTES, M. A.; MOLINARI, S. L.; ZANONI, J. N. \& MIRANDA-NETO, M. H.

Table I. Initial body weight (IBW), final body weight (FBW) and consumption daily of solid and liquid diets of controls (C) and alcoholic rats (A) during 210 days of treatment.All results were expressed the mean \pm standard deviation. $\mathrm{n}=5$ rats per group.

\begin{tabular}{cllcc}
\hline Groups & IBW $(\mathrm{g})$ & FBW $(\mathrm{g})$ & Solid diet $(\mathrm{g})$ & Liquid $(\mathrm{ml})$ \\
C & $323.8 \pm 26.33^{\mathrm{a}}$ & $508.8 \pm 46,14^{\mathrm{a}}$ & $30.0 \pm 2.77^{\mathrm{a}}$ & $43.4 \pm 6.57^{\mathrm{a}}$ \\
A & $310.2 \pm 26.98^{\mathrm{a}}$ & $407.6 \pm 24,7^{\mathrm{b}}$ & $14.4 \pm 1.8^{\mathrm{b}}$ & $26.4 \pm 3.91^{\mathrm{b}}$ \\
\hline
\end{tabular}

Means followed by the same letter in the same column do not differ at the level of 5\%. IBW ( $\mathrm{t}=0.8)$; FBW ( $\mathrm{t}=4.32)$; solid diet ( $\mathrm{t}=9.65)$ liquid $(\mathrm{t}=3.21)$. Coefficient of variation $(\mathrm{v} / \mathrm{c})=1.86$.

Table II. Values obtained by the test "t" of Student when comparing the average number of NADH-d stained neurons of the jejunum in an area of $8.96 \mathrm{~mm}^{2}$ between the regions: Mesenteric (MR) and antimesenteric (AMR) in the controls (C) and the alcoholic group (A), on the $210^{\text {th }}$ day of treatment. All results were expressed as mean \pm standard deviation. $n=5$ rats per group.

\begin{tabular}{lcr}
\hline & \multicolumn{2}{c}{ Groups } \\
\cline { 2 - 3 } Regions & $\mathrm{C}$ & \multicolumn{1}{c}{$\mathrm{A}$} \\
MR & $1131 \pm 89.68^{\mathrm{a}}$ & $1229 \pm 6.38^{\mathrm{a}}$ \\
AMR & $693 \pm 42.10^{\mathrm{b}}$ & $860 \pm 62.44^{\mathrm{b}}$ \\
\hline
\end{tabular}

Means followed by the same letter in the same column do not differ at the level of $5 \%$. MR and AMR in the control group ( $\mathrm{t}=4.3$, vc=1.86). $\mathrm{RM}$ and $\mathrm{RAM}$ in the alcoholic group $(\mathrm{t}=5.87, \mathrm{vc}=1.86)$.

\section{DISCUSSION}

We observed significant statistical differences in the final body weight as well as in the water and food consumption in the alcoholic rats, at the 210 days of treatment, when compared to the controls. In our experiment, the average body weight of the alcoholic rats was significantly smaller when compared to the controls. These observations are in agreement with the works of Ratcliffe (1972), Symons \& Marks (1975), Cagnon et al. and Pereira et al., (2003b) who also observed loss of body weight and smaller consumption of diet and liquids in rats submitted to the experimental alcoholism, through different methods of ethanol ingestion, when compared to the controls.

We believed that the reduced average of body weight found in the alcoholic rats is due to a decrease in the food intake instead of the direct effects of alcohol. This premise is supported by the results described by Weinberg \& Vogh (1988), who observed that the final body weight in rats that received liquid diets with ethanol (alcoholic group) as well as in rats that received liquid diet containing maltose-dextrin (an isocaloric substitute for the ethanol) was reduced when compared to rats
Table III. Values obtained by the test " $t$ " of Student when comparing the average number of NADH-d stained neurons of the jejunum in an area of $8.96 \mathrm{~mm}^{2}$ in the Mesenteric (MR) and antimesenteric (AMR) regions in the controls (C) and the alcoholic group (A), on the $210^{\text {th }}$ day of treatment. All results were expressed as mean \pm standard deviation. $\mathrm{n}=5$ rats per group.

\begin{tabular}{ccc}
\hline & \multicolumn{2}{c}{ Regions } \\
\cline { 2 - 3 } Groups & MR & AMR \\
C & $1131 \pm 89.68^{\mathrm{a}}$ & $693 \pm 42.10^{\mathrm{a}}$ \\
$\mathrm{A}$ & $1229 \pm 6.38^{\mathrm{a}}$ & $860 \pm 62.44^{\mathrm{b}}$ \\
\hline
\end{tabular}

Means followed by the same letter in the same column do not differ at the level of 5\%. MR ( $\mathrm{t}=1.08, \mathrm{vc}=1.86) ; \operatorname{AMR}(\mathrm{t}=2.4, \mathrm{vc}=1.86)$. receiving chow and water (controls). The authors concluded that the reduction in the body weight, in alcoholic and isocaloric, was due to a lower food intake than to a direct effect of the alcohol.

The jejunum myenteric plexus, in both groups, is located between the circular and longitudinal strata of the muscular tunica, as described in the literature about the intramural location of nervous ganglions (Snell and Bloom \& Fawcett 1997) and in the classic works of Auerbach's Plexus Anatomy of Irwin (1931) and Matsuo (1934).

The general arrangement of the myenteric plexus in our experiment showed no variations regarding the circumference regions of the studied jejunum (mesenteric and antimesenteric). However, we verified that the mesenteric regions of the controls and alcoholic rats had a larger neuronal density. Several authors had also found differences in the neuronal density of the myenteric plexus in different regions of the circumference of a same intestinal segment (Irwin) in the large intestine of guinea pigs; Gabella (1990) in the 
colon of guinea pigs; Ali \& McLelland (1979) in the ileum of chickens; Santer (1994) in the mid-region of the small intestine of rats; Miranda-Neto et al. (2001) and Pereira et al. (2003b) in the ileum of rats regardless of the staining technique employed for the membrane whole mounts. According to Miranda-Neto et al., this larger neuronal density of the mesenteric region is likely to happen because of the neurons that promote the innervation of the flat muscular fibers of the intestinal wall added those that innervate the rich vascular plexus. Together, these neurons, through the mesenteric, penetrate the intestinal wall to irrigate it or they leave the intestine to drain it.

The ganglions had round, rectangular and predominantly prolonged shapes with neurons of several sizes and different degrees of enzymatic activity in both groups. As for the size of the cellular body of neurons, there are variations already described and of quite frequent classification of neurons such as small, medium and big (Cook \& Burnstock, 1976; Fehér \& Vajda, 1992; Natali \& Miranda-Neto, 1996).

In an area of $8.96 \mathrm{~mm}^{2}$, the control rats had the following means of NADH-d stained neurons: 1131 $\left(12701\right.$ neurons $\left./ \mathrm{cm}^{2}\right)$ in the mesenteric region and 693 $\left(7728\right.$ neurons $\left./ \mathrm{cm}^{2}\right)$ in the antimesenteric region. This neuronal density, observed in the analyzed regions of the jejunum of our controls, is similar to the density neuronal found by Gabella (1987) in the small intestine of different rodents, who carried out a comparative study correlating the animal size (age), the intestinal length and the thickness of the wall through the technique NADH-d.

We observed a larger neuronal density in the jejunum of the alcoholic rats in an area of $8.96 \mathrm{~mm}^{2}$. We found 1229 (12891 neurons $\left./ \mathrm{cm}^{2}\right)$ and 860 (9598 neurons/ $\mathrm{cm}^{2}$ ) neurons in the mesenteric and antimesenteric regions, respectively. In another study of ours, in which we used the same methodology, we observed an increase of $27.7 \%$ in the number of the NADH-d stained neurons in the mesenteric region and $38 \%$ in the antimesenteric region in the ileum of alcoholic rats, when compared to the controls (Pereira et al., 2003b).

We did not find in the consulted literature the neuronal density of the myenteric plexus of the digestive tract of alcoholic human beings or animals submitted to the ethanol-treatment, analyzed through the membrane whole mount. However, Chesta \& Smok (1993) analyzed the morphology of the muscular layer and the myenteric plexus and, also, the number of neurons in patients with alcoholic hepatic cirrhosis through histological cuts of 5 $\mu \mathrm{m}$, stained with different techniques. They found that the ganglions morphology and the neuronal counting were not significantly different in patients with cirrhosis when compared to the controls, suggesting that the alterations of the motility in patients with liver cirrhosis are not related with the structural changes of the myenteric plexus.

The comparison between the mean number of neurons of both groups, control and alcoholic, shows that the ethanol caused an alteration in the neuronal density. The alcoholic rats had a significant increase in the number of NADH-d stained neurons in the ant mesenteric region although this increase was not significant in the mesenteric region. This increase suggests that the amount of alcohol offered in our experiment, caused a malnutrition state in the alcoholic rats. According to Lieber (1991), alcohol is a substance that causes: a) primary malnutrition, which displaces high energy nutrients from the diet and b) secondary malnutrition, which causes difficulties in the digestion and absorption of nutritious due to gastrointestinal and hepatic complications.

The alcoholic rats in our experiment had a smaller physical growth, with an average weight of $407.6 \mathrm{~g}$. This weight represents $80 \%$ of the average weight of the controls $(508.8 \mathrm{~g})$. According to the literature, animals with smaller body dimension have myenteric plexus ganglions with higher neuronal density with differences between the species and between animals of a same species, but of different ages (Santer \& Baker, 1988; Gabella, 1989; Santer; Johnson et al., 1998), and even with the same age but with different body dimensions (Sant'Ana et al., 1997). Furthermore, the works of Torrejais et al. (1995); Natali \& Miranda-Neto and Brandão et al., (2003) described larger neuronal densities in undernourished rats when compared to controls. According to these authors, this is a reflex of a smaller dispersion of the nervous cells, since the animals presented a smaller physical growth, with a consequent larger neuronal concentration per area.

Our research allows us to conclude that the ganglions and myenteric plexus neurons morphology of the alcoholic rats, observed through light microscopy, were not affected by the consumption of alcohol, when compared to the controls. The ethanol induced a malnutrition state in the alcoholic rats verified by the smaller physical growth; consequently, the alcoholic rats showed a larger neuronal concentration, per analyzed area, due to smaller dispersion. 
PEREIRA, S. M. A.; ARANTES, M. A.; MOLINARI, S. L.; ZANONI, J. N. \& MIRANDA-NETO, M. H. Análisis morfológico y cuantitativo de neuronas mientéricas NADH-d del yeyuno de ratas sometidas a alcoholismo crónico experimental. Int. J. Morphol., 24(3):391-398, 2006.

RESUMEN: El objetivo del trabajo fue verificar, durante un período experimental de 210 días, los posibles efectos del etanol sobre la morfología y densidad de las neuronas mientéricas NADH-diaforasa, en el yeyuno de ratas alcohólicas. Utilizamos 10 animales (Rattus norvegicus) separadas en dos grupos: el control $(\mathrm{n}=5)$ que recibió una dieta proteica normal (22\%) y agua ad libitum; el otro, alcohólico, que recibió dieta proteica normal NUVILAB $(22 \%)$ y brandy de azúcar de caña diluido a 30 Gay Lussac $\left(30^{\circ} \mathrm{v} / \mathrm{v}\right)$. El segmento de yeyuno fue obtenido y sometido a técnicas histoquímicas para teñir las células nerviosas. La observación a través de microscopía de luz mostró que no hubo diferencias morfológicas de importancia entre las neuronas del grupo control y el sometido a alcoholismo. El recuento neuronal en el grupo control, llevado a cabo en 40 campos microscópicos $\left(8,96 \mu \mathrm{m}^{2}\right)$, de las regiones mesentérica y antimesentérica, determinó 1.131 y 693 neuronas, respectivamente, mientras que en el grupo alcohólico se encontraron 1.229 y 860 neuronas, respectivamente. El incremento significativo en el número de neuronas en la región mesentérica, en el grupo de las ratas alcohólicas, es debido a un crecimiento físico menor de esos animales comparados con el grupo control. El etanol causó malnutrición y consecuentemente, las ratas alcohólicas mostraron una densidad neuronal más amplia debido a una dispersión menor.

PALABRAS CLAVE: Yeyuno; Neuronas mientéricas; Ratas; Alcoholismo.

\section{REFERENCES}

Ali, H. A. \& McLelland, J. Neuron number in the intestinal myenteric plexus of the domestic fowl (Gallus gallus). Zbl. Vet. Med. C. Anat. Histol. Embryol., 8:277-83, 1979

Brandão, M. C. S.; Angelis, R. C. ; Souza, R. R.; Frôes, L. B. \& Liberti E. A. Effects of pré and postnatal protein energy deprivation on the myenteric plexus of the small intestine: a morphometric study in weanings rats. Nutrition Research., 23:215-23. 2003.

Bloom, W. \& Fawcett, D. W. Tratado de histología. 12a ed. Madrid, Interamericana, 1997.

Bode, C. \& Bode J. C. E. Efect of alcohol consumption on gut. Best Pract. Res. Clin. Gasteroenterol., 17:57592, 2003.

Cagnon, V. H. A.; Garcia, P. J.; Martinez, F. E. \& Padovani, C. R. Ultrastructural study of the coagulanting gland of wistar rats submitted to experimental chronic alcohol ingestion. Prostate, 28:341- 6, 1996.

Chesta, R. J. \& Smok, S. G. Morfologia de los plexos mientericos del intestino delgado en pacientes con cirrosis hepatica. Rev. Med. Chile, 121:139-43, 1993.

Cook, D. R. \& Burnstock, G. The ultrastructure of Auerbach's plexus in the guinea-pig. Neuronal elements. J. Neurocytol., 5: 171-94, 1976.
Fehér, E. \& Vajda, J. Cell types in the nerve plexus of the small intestine. Acta Morphol. Acad. Sci. Hung., 20:13-25, 1992.

Furness, J. B. \& Costa, M. Types of nerves in the enteric nervous system. Neuroscience, 5:1-20, 1980.

Gabella, G. Fall in the number of myenteric neurons in aging guinea-pigs. Gastroenterology, 96:1487-93, 1989.

Gabella, G. On the plasticity of form and structure of enteric ganglia. J. Auton. Nerv. Syst., 30:59-66, 1990.

Gabella, G. O number of neurons in the small intestine of mice, guinea-pigs and sheep. Neuroscience, 22(2):737-52, 1987.

Gabella, G. Detection of nerve cells by a histochemical technique. Experientia, 25(2):218-9,1969.

Gershon, M.D. The enteric nervous systen. Ann.Rev. Neurosci., 4:227-72, 1981.

Hoyumpa, A. M.; Nichols, S. G.; Wilson, F. A. \& Shenker, $\mathrm{S}$. Effect of ethanol administration on intestinal ( $\mathrm{Na}, \mathrm{K}$ ) ATPase and intestinal thiamine transport in rats. $J$. Lab. Clin. Med., 90:1086-95, 1977.

Irwin, D. A. The anatomy of Auerbach's plexus. Am. J. Anat., 49:141-65, 1931. 
Johnson, R. J. R.; Schemann, M.; Santer, R. M. \& Cowen, $T$. The effects of age on the overall population and on subpopulations of myenteric neurons in the rat small intestine. J. Anat., 192: 479-88 , 1998.

Krishnamra, N. \& Limlomwongse, L. The in vivo effect of ethanol on gastrointestinal motility and gastrointestinal handling of calcium in rats. J. Nutr. Sci. Vitaminol., 33:89-98, 1987.

Levy, J. A. Polineuropatias Alcoólicas. In: Fortes, J.R.A \& Cardo, W.N. Alcoolismo: Diagnóstico e Tratamento. São Paulo: Sanvier, 1991. pp. 151-6.

Lieber, M. C. Hepatic, metabolic and toxic effects of ethanol. Alcohol Clin. Exp. Res., 15:573-92, 1991.

Marcus, R. \& Coulston, A. M. The vitaminis. In: Gilman, A. G.; Rall, T.S. \& Murad, F. The pharmacological basis of therapeutics. New York, Macmillan, p. 1554$5,1985$.

Matsuo, H. A. Contribuition on the anatomy of Auerbach's plexus. Jpn. J. Med. Sci. Anat., 4:417-28, 1934.

Miranda-Neto, M. H.; Molinari, S. L.; Natali, M. R.\& Sant' Ana, D. M. G. E. Regional differences in the number and type of myenteric neurons of the ileum of rats: a comparison of techniques of neuronal evidentiation. Arq. Neuropsiquiatr., 59(1):54-61, 2001.

Molinari, S. L.; Galvanini, P. A.; Pereira, M. A. S.; Furlan, M. M. D.\& Miranda-Neto, M. H. Profile of the cell bogy of Nadh-diaforase positive myenteric neurons from the stomach of rats ( Rattus norvegicus) subjected to chronic alcoholism. Acta Scientiarum. Biological Sciences, 26(3): 349-55, 2004.

Natali, M. R. \& Miranda Neto, M. H. Effects of maternal proteic undernutrition on the neurons of the myenteric plexus of duodenum of rats. Arq. Neuropsquiatr., 54 (2):273-9, 1996.

Pereira, M. A. S.; Orsi, A. M.; Molinari, S. L. \& Garcia, P. J. Alcohol Effects on the principal and cear cells of the caput epididymis of albino rats. Anat. Histol. Embryol., 32:17-20, 2003 a.

Pereira, M. A. S; Molinary, S. L.; Souza, F. C.; André, O. E. \& Miranda-Neto, M. H. Density and Morphometry of myenteric neurons of the ileum of rats subjected to chonic alcoholism. Int. J. Morphol, 21(3):245-50. 2003b.
Preedy, R. V.; Marway, J.S.; Siddiq, T.; Ansari, F. A.; Hashim. I. A. \& Peters, T. J. Gastrointestinal protein turnover and alcohol misuse. Drug Alcohol Depend., $34: 1-10,1993$.

Ratcliffe, F. The effects of chronic ethanol administration em the growth of rats. Arch. Int. Pharmcodyn. Ther., 197: 19-30, 1972.

Ritchie, J.M. The aliphatic alcohols. In: Gilman, A .G.; Goodman, L.S.; Rall, T.S. \& Murad, F., The pharmalogical basis of therapeutics. New York, MacMillan, 1985. pp. 151-6.

Robles, E. A. ; Mezey, E.; Halsted, C. H. \& Schuster, M. M. Effects do ethanol on motility of the small intestine. Johns Hopkins Med.,135:17-24, 1974.

Sant'Ana, D. M. G. ; Miranda - Neto, M. H. ; Sousa, R. R. \& Molinari, S. L. Morphological and quantitative study of the myenteric plexus of the ascending colon of rats subjected proteic desnutrition. Arq. Nerop., 55:687-95, 1997.

Santer, R. M.; Baker, D. M. Enteric neuron numbers and sizes in Auerbach's plexus in the small and large intestine of adult and aged rats. J. Auton. Nerv. Sys., 25: 59-67, 1988.

Santer, R. M. Survival of the population of NADPH diaphorase stained myenteric neurons in the small intestine of aged rats. J. Auton. Nerv. Syst., 49:115-21, 1994.

Snell, R. S. Histologia Clínica. Rio de Janeiro, Interamericana, 1885.

Sternini, C. Structural and Chemical organization of the Myenteric plexus. Ann. Rev. Physiol., 50: 81-93,1988.

Symons, M. A. \& Marks, V. The effects of alcohol on weight gain and the hypothalamic pituitary - gonadotrophin axis in the maturing male rat. Biochem. Pharmacol., 24:955$8,1975$.

Torrejais, M. M.; Natali, M. R. M. ; Conegero, C. I. \& Miranda - Neto, M. H. Effect of proteic malnutrition after breas - feeding on the morphology of the intestinal wall and myenteric neurons of the ileum of rats. Rev. Unimar, 17:315-27, 1995.

Weinberg, J. \& Vogh, A. W. Effects of etanol consumption on the morphology of the rat seminiferous epithelium. Androl., 9:261-9, 1988. 
PEREIRA, S. M. A.; ARANTES, M. A.; MOLINARI, S. L.; ZANONI, J. N. \& MIRANDA-NETO, M. H.

Correspondence to:

Prof. Dra. Marli Aparecida dos Santos Pereira

Universidade Estadual de Maringá

Avenida Colombo, 5790- $\mathcal{B l o c o} \mathcal{H} 79$

Departamento de Ciencias Morfofisiológicas ( $\mathcal{D} C \mathcal{M})$

Maringá, Paraná,

BRASIL

Email: maspereira@uem.6r
Received: 20-04-2006

Accepted: 11-06-2006 